\title{
The Nanking Atrocity: Still and Moving Images 1937-1944
}

\author{
Gary Evans \\ Department of Communication, University of Ottawa, Ottawa, Ontario K1N 6N5, Canada; \\ E-Mail: evansg@uottawa.ca; Tel.: +1 5144898737 \\ Submitted: 8 October 2013 | In revised form: 8 December 2013 | Accepted: 8 January 2014 | \\ Published: 17 February 2014
}

\begin{abstract}
This manuscript investigates the facts of publication of the images of the Nanking Atrocity (December 1937-January 1938) in LIFE and LOOK magazines, two widely read United States publications, as well as the Nanking atrocity film clips that circulated to millions more in American and Canadian newsreels some years later. The publishers of these images were continuing the art of manipulation of public opinion through multimodal visual media, aiming them especially at the less educated mass public. The text attempts to describe these brutal images in their historical context. Viewing and understanding the underlying racial context and emotive impact of these images may be useful adjuncts to future students of World War II. If it is difficult to assert how much these severe images changed public opinion, one can appreciate how the emerging visual culture was transforming the way that modern societies communicate with and direct their citizens' thoughts.
\end{abstract}

Keywords: Nanking Atrocity; impact of still and moving images

\section{Introduction}

In 2008, the seventieth anniversary of the Nanking Atrocity passed with limited international interest in the event that marked Japan's depredations in the Chinese capital city of Nanking (Nanjing) from December 1937 through January 1938. The event, including the wholesale murder of captured soldiers and civilians, and the rape of thousands of women, later became iconic as the "Rape of Nanking". This study will investigate the facts of publication of the images from Nanking in the weeks and months following the event, in LIFE and LOOK magazines, two new United States photograph journals competing with each other and with the newsreels. They claimed a readership of seventeen million and one million respectively. The photograph journals' images were Japanese soldiers' 'souvenir stills', not meant for publication, but smuggled out of China to the West. Several western observers in the International Safety Zone filmed evidence of the human tragedy surreptitiously, but their images did not appear in newsreels until several years later. The publication of the still and moving atrocity photographs were a kind of novelty, signaling a shift in what public decorum would now tolerate. A few years later, the bloodbath of World War II achieved a new reality. As Susan Sontag generalized, photographs were a species of rhetoric that reiterated, simplified, agitated and created 
an illusion of consensus. Their daily pervasiveness during the conflict perhaps began to dull, if not corrupt the senses leading to our contemporary world of image saturation that Sontag believed diminishes morality and even numbs viewers to the point of indifference. If brutal images from Spain's civil war had begun this decade's cascade of horror in 1936, the Nanking images elevated shock effect. Incidentally, they helped to sell millions of magazines ([1], Sontag extended these thoughts in a provocative article in 2002 [2]).

By the 1930's photo-magazines were recognizable adjuncts of the news business in Europe, the Soviet Union and the United States. Two features about them are striking:

Photographs dominated their pages and the stories were generally simple or captions alone. They appealed to a readership that was, as an aggregate, young and more inclined to learn from pictures than from written sources. Second, these media tended to serve as mirrors and reinforcements of the dominant ideology of the country of origin. In Britain, for example, Picture Post came into existence in October 1938 and under the editorial guidance of Stefan Lorant and Tom Hopkinson, devoted itself to reflecting the national mood as the economically depressed nation slid toward the precipice of war while also appealing to the perennial whimsies of a young generation [3]. Its picture stories combined social comment with reportage to promote a kind of left-liberal humanitarianism to which the establishment had to adapt. Importantly, it introduced 'new ways of seeing' derived from radical publishing in Europe into the commercial culture that appealed to a new and growing audience. The multiple characteristics of picture magazines was their reductive simplicity, emotional appeal, and yet serious intent to inform. In the United States, Life and Look magazines shared these values as business ventures trying to build a readership of millions and to compete with newsreels to deliver the visual rhetoric of a world in action. Of course there were exceptions to the Life and Look approach. For example, Agee and Evans "Let Us Now Praise Famous Men", originally produced for Fortune magazine with governmental financing, was unique in its even-handed grappling of what Agee called the "cruel radiance of what is" of America's hard edged social realities. It was also reminiscent of the more sober Illustrated America and Harper's Weekly in the 1890s.

Edward Bernays and Walter Lippmann were influential thinkers in the 1920s who explored the role of public opinion in a democracy. The former was especially important in articulating the rules of modern advertising while the latter believed that in a democracy, an educated elite should direct and manipulate public opinion. Both built upon an existing understanding that emotions kindled by imagery tended to be an effective way to reach the millions of malleable citizens. Lippmann had said it was impossible to credibly inform the masses on important issues and then ask them to decide; decision was the job of the educated elite. John Grierson, a Scotsman from Britain who was studying public opinion in the United States at the University of Chicago, argued with Lippmann and claimed that half the equation was valid: it was possible, he believed, to use the emotional appeal of imagery to educate and motivate the individual in order to give him a the feeling of having a stake in society. Grierson returned to Britain to apply the power of visual rhetoric to documentary film. Besides informing and moving the viewer, he found one great strength of film was its appeal to the young, to the marginally educated, and to those semi-literate who did not read much at all. He understood that the typical citizen was more adrift than not, and that emotional imagery, in the form of the creative treatment of actuality, provided another form of factual education. He claimed the purpose of documentary was propaganda as education; its images could create democratic loyalties and intelligent understanding of the contemporary world. Grierson never denied that given a typical audience, documentary film, photojournalism and newsreel photography all exhibited a lack of intellectual rigor. They tended toward the sensational and sentimental, but those were the elements that impelled millions to act. In the complex world of the 1930s, there was a concerted struggle to use images to attract the loyalties of their citizens [4].

Whether they were images from the Spanish Civil War or Japanese depredations in Asia, the object of the new visual culture was to treat the unimagined experience and to render it emotional ([5], pp. 9-14, $47,57,62$ ). Images of children figured often because they were blameless victims of social circumstances. As we shall see, the photograph of a child casualty in the 1937 Japanese bombardment of Shanghai's railway station evoked cognitive emotional empathy, moral awareness, and identification with alien victimization. That photo, whether candid or arranged, became so iconic, that today it stands as a lifelike sculpture that a visitor sees first when entering the Nanking Massacre Memorial Hall (Figure 1).

Figure 1. Baby Ping-Mei. Source: Karin Doerr.

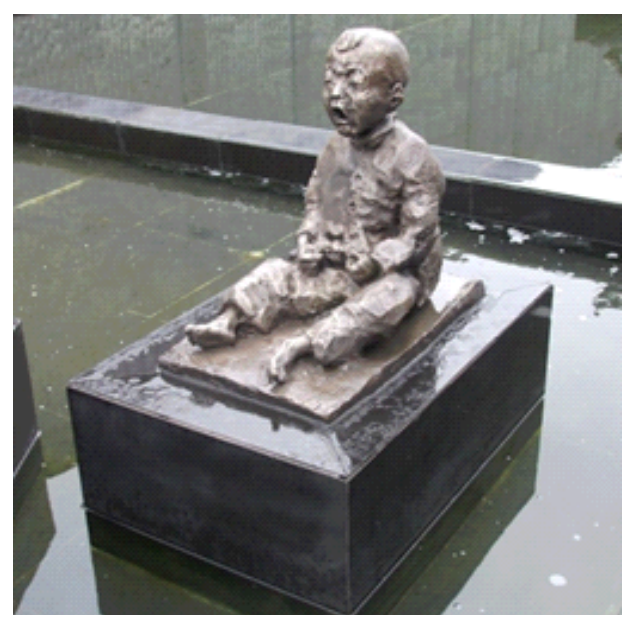


Because Asia remained an alien bailiwick for western correspondents, there were not many still and moving images that had emerged from China, at war with Japan since 1931. If the American public's reaction to the still photographs from Nanking was generally one of shock, there seemed to be a somewhat indifferent long-term emotional involvement, due likely to inherent western racism or the remoteness of a conflict that was 3000 miles away. Archibald MacLeish once referred to such reaction as "the superstition of distance", being so far away, a viewer might conclude that violence, lies and murder on another continent were not believable ([5], p. 137). Racism, remoteness, incredulity, and paucity of correspondents are elements that anchor this study of the Nanking Atrocity's images.

As George Roeder Jr. stated in his seminal study of the American visual experience in World War II, it is difficult to assume precisely measurable or predictable effects of still and moving images upon public opinion in wartime America ([6], pp. 1-25, 81-104). The same applies prior to the war, although there was significant interest in visual depiction of world events, from Spain's civil war to Japanese militarism in Asia. In January 1938 the American public flocked to see to the newsreel footage of the Japanese bombing of the American cruiser Panay outside Nanking. It was a vicariously lived experience, and not long afterward, Life and Look's still photographs of the Japanese depredations within the city probably added to growing American outrage at Japan ([7], pp. 3-14; [8]). In the context of the time, emotion triggered moral revulsion and both elements reinforced the humanist western tradition.

Still it took years and actual war for the smuggled Nanking atrocity film clips to circulate in American and Canadian newsreels. In the United States, as part of basic training, millions of recruits saw the Why We Fight series in which the virulent phrase the 'Rape of Nanking' became a popular slogan; millions more saw the same series in and out of theatres. In Canada, these and other film images were matched to a caricature of the duplicitous Japanese enemy as individually trustworthy yet collectively treacherous. The residual impact of these and the still photographs that Americans saw cannot be measured scientifically, but in the modernist tradition of moral integrity, their propaganda value was clear. Once war came, the American newsreel treatment of the Japanese aggressors was overtly racist; the Canadian propaganda effort, headed by John Grierson, used actual and manufactured atrocity footage to demonstrate fanatic Japanese militarism in order to strengthen Canadian national morale. The lasting (anti-Japanese racial) impression created by Canadian theatrical newsreels would impel the public, already bitter over Japanese abuse of Canadian prisoners of war, to mobilize in common purpose. If one American epithet referred to the Japanese racially as "buck-toothed," Canadians saw Chinese-staged (black propaganda) images of Japanese soldiers attacking women and bayonetting a baby. For both countries, the newsreels' use of gruesome Nanking images accompanied by a cascade of explanatory verbiage and moral invective reflected an informational world where news was as much about emotional imagery as about fact.

As applied to today's geopolitical tensions between China and Japan, images and words continue to resonate regarding events related to Nanking ([9], see [10]). The best-selling book by the late Chinese-American author, Iris Chang, echoed the Holocaust as a paradigm of memorial culture, referring to the Nanking tragedy in her title as 'the forgotten holocaust' ([11], see also [12]), causing instant controversy for its inaccurate association with the genocide of Europe's Jews [13,14]. In 2007-2008, the Chinese diaspora was reminded of the memory of the atrocity both in print and in three films by a Chinese, Japanese, and western filmmaker [15]. Debate continues to revolve around Japan's refusal to acknowledge fully and publicly its responsibility as a perpetrator. The impressment of Korean women as sex slaves is now a more familiar issue while Nanking is a less cited symbol of Japanese sexual ravages of Nanking women and the related brutality of its civilians. This may be because none of the world economic powers wishes old wounds to cause a breach in the thrust of today's consumerist world economy. Besides, China is very reluctant to allow the genie of public anger to percolate through its population, lest it lead to unintended political consequences for itself. This study concludes that the images and doctored footage from Nanking should be included as part of understanding a general cultural shift that accorded visual images a new respect. What remains difficult to gauge is the impact of exposure to these barbaric images. Then, they were part of the need to mobilize public opinion for war. Today, one fears they will not be used out of context as part of a growing public acceptance of, or indifference to the saturation of obscene images. If employed judiciously and in context, they may lead new generations of students of World War II to grasp the impact of visual imagery on mass populations.

\section{Background}

Japan had set up a puppet regime in Manchuria following its 1931 invasion. In July 1937, using a skirmish as a pretext to attack Shanghai, Japan launched a full scale invasion of China proper. Nationalist forces under Chiang Kai-Shek fought fiercely, but were defeated by aerial bombardment and superior Japanese troops. Chinese nationalist armies withdrew to the capital of Nanking, slowing the Japanese advance by using a scorched earth policy that left the enemy no food and little shelter, a policy that caused the Chinese civilian population much grief. The Japanese were surprised by the ferocity of the nationalist forces' 
resistance and vowed revenge. Nanking's pre-invasion civilian population of one million was already reduced by up to three quarters before the Japanese assault by 200,000 troops. When they reached Nanking in December, the Chinese nationalists had laid waste key buildings and moved the capital to Chungking. Chiang withdrew the majority of his troops, leaving 75,000 to defend the city. As the invaders took and sealed off Nanking, 50,000 Japanese soldiers unleashed a campaign of unrestrained brutality. Emperor Hirohito's uncle, Prince Asaka, issued an order, "Kill All Captives". This encouraged lower echelon Japanese officers, short of supplies and anxious to build morale, to issue a policy of "Burn All, Loot All, Kill All".

Unobserved by world media and contradicting their own propaganda about kind Japanese soldiers, Japanese forces engaged in a murderous rampage until the end of January 1938. They sought out and machinegunned or bayoneted tens of thousands of Chinese soldiers who had surrendered. The victims believed they were to be imprisoned, not shot by gunners hidden behind camouflaged walls. Thousands more civilian males of military age met a similar fate. In the final disgrace, troops raped indiscriminately some 20,000 Chinese women and girls, many of whom they murdered. The postwar Tokyo Tribunal established the "traditionalist" victim total of 300,000 [16] that has been accepted as valid ever since $[17,18]$. Japan denies responsibility for letting loose and ordering its soldiers to perpetrate war crimes [19-21].

In Nanking, journalists Hallett Abend and Frank Tillman Durdin of The New York Times reported on the unfolding tragedy on 10-11 December 1937. Their photographs depicted Chinese refugees, some waiting to be admitted to the "safe" International Safety Zone that foreign residents had established. As the city fell, journalists left Nanking to file their stories in Shanghai. They were not allowed to return until the end of January. So there were neither photographs nor western journalists to witness the fall of Nanking on 14 December. In fact, the news focus shifted dramatically on 13 December, when The New York Times reported that Japanese planes had attacked the American gunboat Panay not far from Nanking, resulting in the loss of several lives. The Times' photograph showed the Panay in its death throes after its crew and passengers had abandoned ship. For the next three weeks, the sinking of the Panay remained front page news in many U.S. newspapers [22]. On 15-17, 19$21,25,26$, and 28 December, the lead stories in the Times dealt with Japan's insistence the Panay attack was an error, for which it proffered apologies (and eventual restitution). In the midst of the hysteria about the gunboat, Durdin filed a story from Shanghai on 17 December that news reports of atrocities at Nanking were like "...stories of war hundreds of years ago...when...a conquered city with its helpless inhabitants should be given over for twenty-four hours to the unbridled lust of the victors" ([23], p. 8). He concluded, "[the] terrorized population lives in fear of death, torture and robbery". On 18 December, under the banners "Butchery Marked Capture of Nanking" and "All Captives Slain", he reported the blanket looting and violation of women with a detailed description of Japanese depredations and rapes. He reported on 27 December that chaos and anarchy were facts in Japanese-occupied provinces; the story included a picture of Japanese troops marching to Nanking, but none from the city itself.

On the same day, LIFE published a pictorial essay on the Panay, using frames from the film that two newsreel photographers, Norman Alley and Eric Mayell, had shot while on board the doomed vessel. The ship sinking was the main story, and absence of dramatic photographs left the Nanking collapse a poor second. In the pre-television age, the public had developed an appetite for the visually stimulating experience of the newsreel (Figure 2).

The next day, the Times played up the Panay incident not only because American national honor had been compromised, but also because there was a film record of the attack on their neutral ship. The footage was speeding its way across the ocean and continent, soon to appear in newsreels. This raised significant public anticipation and on 30 December, newsreel theatres reported lines around the block.

This fed the Panay hysteria even more. LIFE reported that audiences allegedly broke into repeated applause after seeing the heroism of the ship's officers and civilians. Few knew that President Roosevelt had asked that the most damning footage, showing Japanese planes coming at the Panay at deck level, be censored. This was probably because negotiations regarding Japan's willingness to apologize and indemnify the United States were at a critical juncture. The footage was cut. Washington learned through code breaking that atrocities were occurring in Nanking but their source remained top secret. Without newsreel footage and correspondents' confirmation from Nanking, the public remained focused on the Panay spectacle (see $[20,24])$. For three weeks, newspapers in the United States made so much of the Panay sinking, that the Nanking Atrocity took a poor second in influencing pro-China and anti-Japan public opinion $[25,26]$.

Figure 2. Sinking of the SS Panay. Source: The Denver Post/ Getty Images.

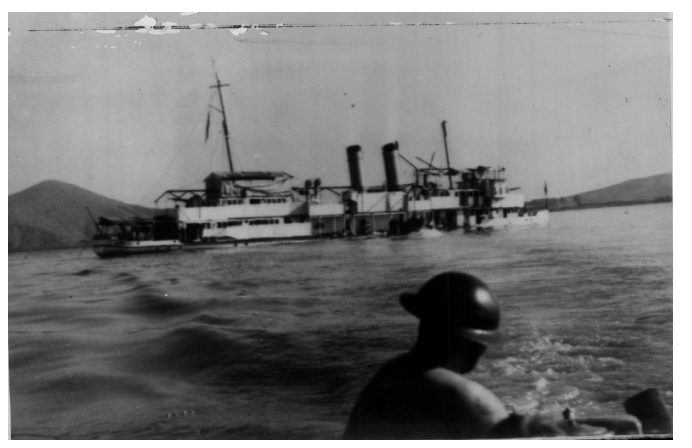


One can argue that the public's response to the Panay sinking took precedence because it was obvious that there was a shared national concern about the fate of one of its ships. It was only much later that stories appeared in mainstream print outlets like Time, Reader's Digest and Far Eastern filed by the western witnesses in the Nanking International Safety Zone $[27,28]$. By then, time had diminished the newsworthy immediacy of the event $[29,30]$.

Henry Luce owned LIFE, TIME and FORTUNE magazines. Born in China to American missionary parents, he remained a lifelong champion of his birthplace and was probably America's most cogent proChina spokesperson ([31], pp. 28, 30; [32,33]). He launched LIFE as a weekly news magazine in November 1936, with a strong emphasis on photojournalism. By 1938, he claimed its circulation was 17 million. With some prescience, a full week before the fall of Nanking, LIFE ran a cover picture of a Japanese soldier with a machine gun and the caption "Fatalist With Machine Gun". The issue featured Japan's conquest of Asia, with one story about Japanese soldiers, headlined "Japan's Army Slogs Down Asia on Schedule Time". To a long shot of Japanese soldiers marching, the caption remarked "happy at their work".

LOOK magazine, competing with the more popular $L I F E$, also celebrated America as a middle class experience. As a general-interest magazine, it cultivated a largely superficial approach to contemporary society, filling its pages with photographs of movie stars and casual or striking events. Because it took months to set up its biweekly issue, on 21 December 1937 LOOK ran a photomontage of the August 1937 bombing of Shanghai. It was a tragedy unrelated to the disaster unfolding in Nanking. Using frames of moving picture film shot by Hearst cameraman Wong Hai-Sheng, one shot became one of the most iconic of the prewar period, showing a baby sitting amidst the wreckage of a bombed out Shanghai railway station [34,35] (Figure 3). LOOK's account of the barbarity of Japanese aerial warfare shocked the world. An estimated 136 million people saw the shot on newsreel screens or in print ([36], p. 260). United China Relief used this image to sell millions of Christmas cards and to raise millions of dollars for Chinese aid. Titled the Ping Mei card, the reverse side read: "This is Ping Mei-a child of China-...he is one of 50 million refugees who desperately need food, clothing, shelter, medical aid". Time magazine published it too, while appealing for money and underscoring the common interest and goals shared by the Chinese and Americans ([37], p. 55; $[38,39])$.

LOOK's use of emotive captions added weight to the frames of the bombed railway station. Its twopage feature titled "A Chinese Baby Survives an Air Raid" displayed five frames including the above mentioned event with a Chinese rescuer in the image (Figure 4).

A first picture explained the image of a Chinese man picking up the infant lying on the railroad tracks half hidden under the wreckage. A second still showed the man carrying the baby through the wreckage. A third photograph had him crossing the track to a platform while the caption explained the unannounced Japanese attack on this civilian facility. A fourth photograph depicted the infant, an older child standing next to his rescuer, the wreckage, and a dead child lying on the tracks nearby. The caption read: "...a child and man approach (above) to take the baby to a near-by first aid station. At the right lies the body of a 14year-old boy, one of the 15 children found dead in the raid. In bombing Shanghai, Japan struck at China's largest, wealthiest city. Planes also have bombed Nanking, China's capital". The shameful image of the lone infant victim was evocative propaganda, a picture triggering a natural human response of revulsion. This iconic image helped construct a collective memory about the horrors of Japanese aggression and public discourse revolved around it as the Luce publishing empire helped keep it alive ([40], see $[41,42]$ ) (Figure 5).

Figure 3. Baby Ping-Mei. Source: LOOK Magazine.

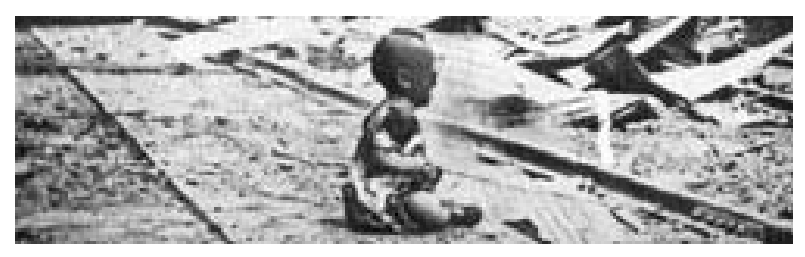

Figure 4. Filmed images of baby Ping-Mei. Source: LOOK Magazine.
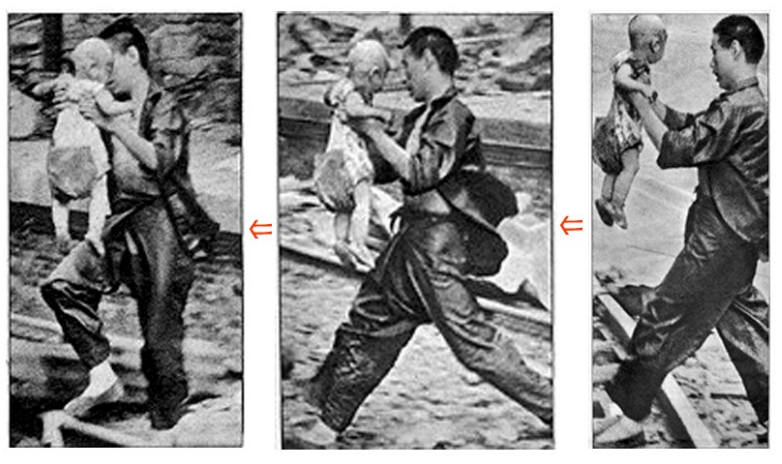

Figure 5. Rescue of baby Ping-Mei. Source: LOOK Magazine.

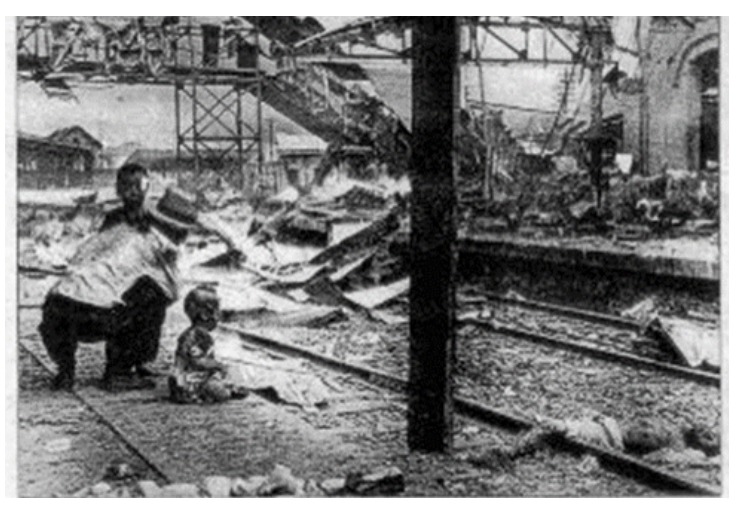


Situating the photograph in a related, but different context, a final photograph caption, titled "Lying on a Stretcher", depicted the infant on a sidewalk, receiving "first aid from a Chinese boy scout..." The text continued, "three weeks later, on the occasion of the Japanese bombing of Nanking, the governments of the U.S., Britain and France sent a note of protest to the Japanese government against the bombing of civilian populations. But aerial raids continue, with an increasing toll of dead. Chinese bombers and gunners, as well as Japanese, have been responsible for some of the deaths of innocent non-combatants-American and European as well as Oriental-in this undeclared war" (International News photographs [34]).

The undoctored newsreel footage indeed revealed a tragic and hopeful moment, the rescue of a baby after Japan bombed the railway station, intentionally or not. Yet the arrangement of film frames could lead a doubter or denier to claim that perhaps the entire event was staged for the camera or the baby was placed on the track after his rescue and then left to cry. The more significant historical fact remains that this child became the icon that spoke of Japan's careless attack on innocents in a civilian locale. One notes how different the film clip appears compared with the verbiage attached to the still frames.

While it is difficult to measure the impact of this visual news item in isolationist America, a Gallup Poll taken late in 1937 revealed that if the Ohio floods interested Americans most in the preceding year (28.3\%), the Sino-Japanese war had practically the same effect (27.8\%). By May 1939, seventeen months after the Nanking atrocities, polls revealed that sympathy for Chinese rose from 43\% in August 1937 to 74\% ([37], pp. 45, 46).

Having covered the Panay story in December exclusively, LIFE did not want to be scooped by $L O O K$, so its editors ran a grisly photograph on 10 January 1938: a severed Chinese head with a cigarette in its mouth (Figure 6).

The macabre text read in dramatic language that echoed Time magazine: "Chinese head whose owner was incorrigibly anti-Japanese, wedged in barbed wire barricade outside Nanking just before the city fell December 14...Quite possibly the worst holocaust [43] in modern history took place behind an official news silence in China's capture capital of Nanking between December 10 and 18...In the indescribable confusion the Japanese shot down everyone seen running or caught in a dark alley. In the safety zone 400 men were tied together and marched off to be shot. A few uninvestigated cases of rape were reported...The Japanese army permitted organized looting by its men presumably because its supplies are getting low..."

This atrocity photograph would not likely have been published if it had depicted a Caucasian victim [44]. The fact was that once World War II began, Life was so reluctant to publish images of American dead, that its first such photograph appeared only in September
1943, eleven months after the soldiers depicted had died in battle. Life's editorial decision to let the Nanking photograph out reflected a double standard: the Oriental as Other and a feeling that many viewers would consider the sight of Orientals murdering each other as nothing more than a confirmation of Asian barbarism, as opposed to eliciting sympathy, horror or motivating action.

The article ignored the issue of widespread rape, choosing a photograph of a Chinese father carrying a baby mortally wounded by a Japanese bomb fragment and another of Chinese soldiers and civilians at a city gate with Japanese soldiers hauling carts of looted supplies. Its caption read, "the organized looting of Nanking would indicate that the Japanese Army Commissariat needs food more than prestige". A two-page photograph spread followed, of Nanking refugees on 5 December fleeing on a Yangtze riverboat. The text defended the Nationalists' scorched earth policy as the way to defeat the Japanese [45].

While both LOOK and LIFE had published photomontages reporting the military debacle in Nanking, because virtually all correspondents had been evacuated, there were no visuals conveying the scope of violations and breadth of the massacre. LOOK ran a feature on war propaganda on 15 February 1938 without defining what constituted war propaganda, good or bad. One page was devoted to Shanghai victims, depicting an old woman and a child, a mother nursing her infant, and another carrying her child through Shanghai streets. The pain of innocent civilians was clear, yet public decorum still demanded avoidance of the obscenity of death and blood.

On 18 April LIFE covered the Nanking massacre again with text that informed the American public of the depredations in detail. "These are the same soldiers who through last Christmas and New Year's treated Nanking, China's captured capital, to the most appalling mass atrocity since Genghis Khan. They raped Chinese women by the thousands, bayoneted and burned unarmed Chinese men alive in equal numbers, suffered the inevitable loss of morale. Since then the Japanese have been stopped and defeated by the Chinese" [46].

Figure 6. Severed Chinese head. Source: AP Photo.

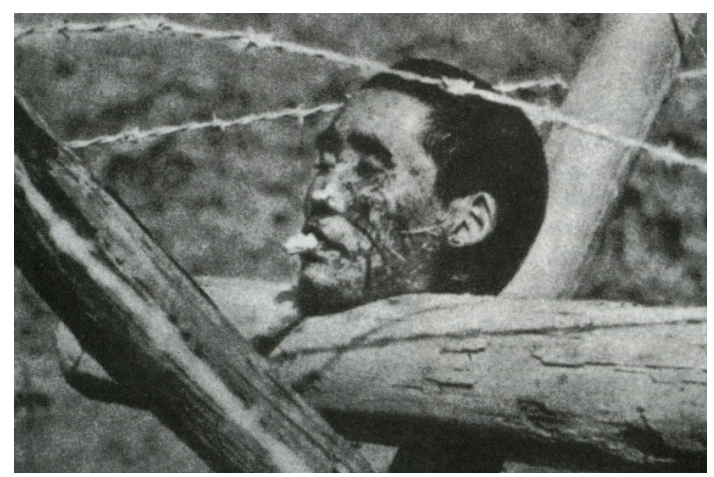


The photograph of Japanese soldiers dozing harmlessly in a Chinese temple did nothing to illuminate or nuance the text. Three weeks later, LIFE displayed a series of photographs of Chinese child actors touring the countryside in a propaganda play about Chinese farmers uniting against a Japanese bully. In order to widen the propaganda effect of Chinese resistance, on 16 May, LIFE put a head shot of a determined looking Chinese soldier on its cover with the caption "Defender of China".

The accompanying feature boasted (incorrectly) that China was putting the Japanese army on the run and that China's odds to win were better than 50-50.

A powerful addition was a series of ten photographs of Japanese atrocities, frames taken from unattributed film footage. American missionary John Magee had filmed hospitalized victims surreptitiously in the International Safety Zone during the chaos, and fellow American John Fitch smuggled this footage out of China early in 1938. Fitch circulated it to limited American audiences to inform them of Japanese brutality, but exhausted by his efforts, he soon ceased his one-man campaign. Perhaps because events in distant Asia had less resonance than almost daily Eurocentric news, the film lay dormant until 1942, when portions of it appeared in a Canadian newsreel $[47,48]$. The above stills were preceded by the text: "the most dreadful picture of the rape of Nanking this amateur photographer could not take. He knew that if he filmed civilians being shot down or houses looted and burned, he would be arrested and his camera smashed. Besides he was too busy, like other foreign missionaries and doctors, saving what civilians he could. But for two weeks he saw an army completely out of control, raping, burning, killing and robbing and destroying without check. He saw a Japanese embassy completely powerless to restrain its own men. In foreign hospitals in and around Nanking he saw hundreds of innocent victims of 'totalitarian war".

Accompanying each photograph was an explanation: 1. Wounded Chinese in primitive basket who was transported to emergency facility. 2 . Survivor of family of 11 standing among bodies 3.Wounded woman whose husband and child were killed. 4. Disfigured burned man, tied with 100 others, doused with gasoline. 5. Man with bayonet gashes, who refused to yield his women to Japanese. 6 . Woman nearly decapitated 7. A 14-year-old boy beaten with an iron bar. 8. Man (police) struck with axe, recovering in hospital after feigning death by firing squad. 9. A 19-year old woman stabbed 29 times, later had a miscarriage in a refugee hospital. 10. Body left to rot in roadside pond.

Six months after the fact, these were among the most inflammatory photographs of the Asian conflict ever shown to the American public and an early use of the term "Rape of Nanking". These must be added to evidence that was steering (a still largely isolationist) United States public opinion to a stronger pro-Chinese/ anti-Japanese position. The next week, a photograph essay described Chinese troops going into action and achieving a victory; a week after that, war photographer Robert Capa's photographs depicted Chinese civilians witnessing air battles over the city of Hankow. Capa's images of war would become icons of the era even though these photographs of a mourning Chinese mother and the city of Canton under fierce Japanese bombardment were not reproduced in the millions as were those of baby Ping Mei. The text predicted accurately that these images of dead and wounded and a city destroyed were curtain raisers to the next war in Europe [49]. LIFE had shot its bolt as these were the last Nanking references in 1938. There were eight more issues in which China was mentioned, but nothing was as sensational as the Nanking photographs [50].

Notwithstanding LIFE's larger readership, in November it was LOOK that delivered the most graphic photographs of Japanese outrages (probably in Nanking), including the Japanese bayoneting of Chinese prisoners of war while soldiers watched (Figure 7). The LOOK captions were as graphic as the pictures. Under the headline "Killing For Fun!" the text read: "Hands Tied, Chinese prisoners are used as live targets for bayonets of Japanese recruits. In the foreground a captive is being tormented. Another (left rear) is being stabbed to death. A third (center) has just received the death thrust. A fourth (rear) is being driven into the pit" $[51,52]$. Additional text on the page charged the Japanese with butchering Chinese and burying them alive, merely for amusement, or to inspire raw recruits to kill. The writer explained:

"We are sending you some pictures of killers in the act of killing. We have plenty of hard boiled correspondents here-Steele of the Chicago Tribune, Durdin of the New York Times, Beldon, an exUnited Press reporter, Victor Keen of the New York Herald Tribune, and others and all of them reckoned the pictures to be the worst things they had ever seen in China, bombing aftermaths and battlefields thrown in.

The pictures were taken in Nanking and Soochow recently, that can be judged by the fact that the men are in their summer uniforms. In other words, the killings happened at least six months after the occupation of those cities, when some blood lust, however bad, was to be expected. Thus, these pictures must come under the heading of diversion, or else the executions were staged to put the killer instinct into freshly drafted troops.

The Japanese soldier-photographers sent the films to Shanghai for developing and printing. They sent them to a Japanese-owned shop and Chinese employees did the natural thing in exceeding the original printing order. Hence these pictures found the light.

These Sons of Heaven went one worse than the 
Romans who, even if they sent their gladiators into the arena wearing half-inch armor, at least gave their victims a short sword and a sporting chance. As you will perceive, all these Chinese soldiers and civilians were led into the killing pit with their arms pinioned."

Captions explained that these were Japanese recruits at bayonet drill. Using Chinese prisoners as targets was a practice that was considered the proper way to season newcomers. This photograph was among sixteen souvenir photographs taken by Japanese soldiers. Duplicated secretly, these grisly images made their way to the West eventually and the entire set was used at the postwar Nanking War Crimes Trial in Tokyo (1946-1948).

On the following page, a photograph depicted Japanese soldiers watching execution of Chinese men. The caption read: "Rivers Run Red as Chinese are executed beside a stream. Several hundred Japanese soldiers are gathered around, watching the slaughter. The man in the foreground is toppling over dead. His head may be seen in the crook of his arm. The next victim is in place" (Figure 8).

A second picture claimed, "Five Chinese Prisoners are Buried Alive, in this, one of the most gruesome of all wartime pictures. Enraged by the stoic calm with which the Chinese defenders are meeting their attack, the Japanese are more determined than ever to bring them to their knees. This war, now in its third year, is one of the most brutal in history" (Figure 9).

A larger photograph depicted Japanese soldiers with fixed bayonets aimed at two bound Chinese, one tall, one short (Figure 10). The text stated: "The Big Boy Was Beheaded because he stepped on a telephone wire, but the Japanese soldiers spared the life of the little fellow. Because of a shortage of food, many prisoners in the bloody arena are beheaded. Both the Japanese and Chinese face death with a calmness astonishing to westerners" [51].

Figure 7. Japanese soldiers bayonet Chinese prisoners. Source: Keystone/Getty Images.

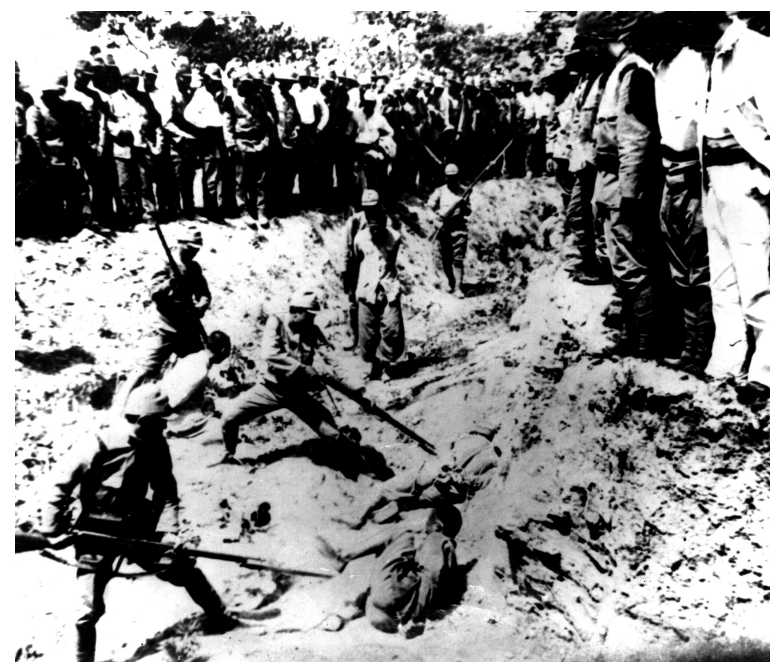

Figure 8. Beheading a Chinese soldier. Source: Robyn Beck/Getty Images.

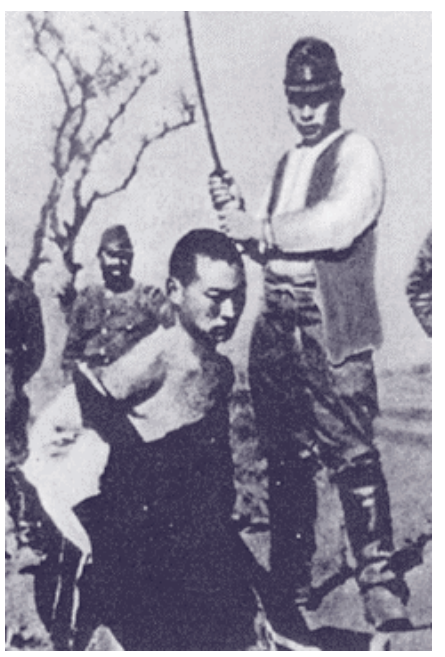

Figure 9. Burying Chinese prisoners alive. Source: Keystone/Getty Images.

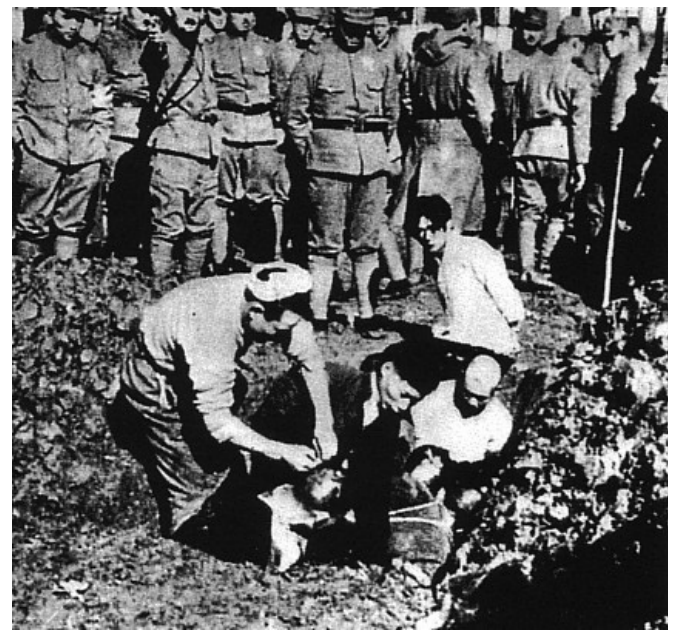

Figure 10. Japanese abuse young Chinese captives. Source: LOOK Magazine.

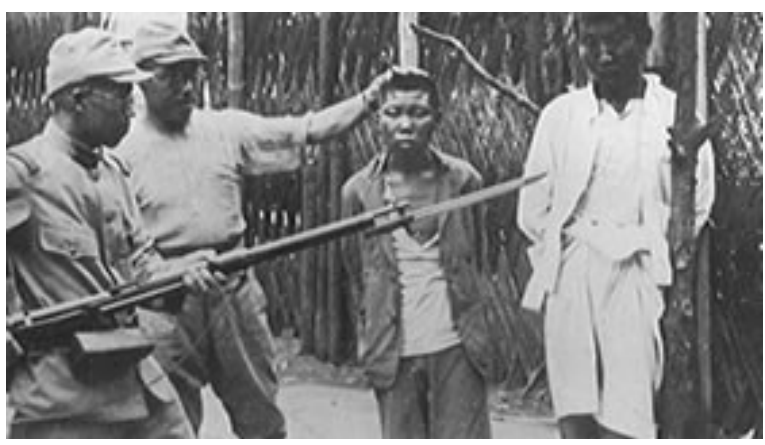

Another image of live burials appeared in the journal Pictorial Review with a story by Betty Graham titled, "Hundreds of Thousands Slaughtered in New Wave of Bestial Jap Atrocities" [53-56]. The photographs' impact should be included in explaining a Gallup Poll rise in anti-Japanese American public opinion [57]. If a photo's visual syntax is universally comprehensible, it is difficult to assert what the viewers' possible re- 
sponse to atrocity photographs would have been: perhaps a combination of horror, anger and to a lesser degree in isolationist America, a desire to punish the perpetrators [7,58-61]. A recent historiographical book on the moral, political and educational aspects of the atrocity surveyed Chinese, Japanese and transnational authors, but did not attempt to gauge the impact on public opinion that pictures like these had when circulated in the millions [62].

Nanking disappeared from public discourse after 1938. Some found the atrocity stories too shocking, believing they were similar to (untruthful) black propaganda of World War I. Others had inverse attitudes: sympathy for the Chinese in Asia and prejudice to Chinese living in their city. Perhaps because of squeamishness about rape and barbarism ([10], p. 16; [6369]), or because they violated standards of decency or because of general provincialism, the Nanking horror slipped from public consciousness until America was at war. Japan's attack on Pearl Harbor in 1941 became America's rallying cry. Only then did the 'Rape of Nanking' join wartime iconography $[70,71]$.

In contrast to the United States, Canada had no weekly national pictorial magazine. Its primary national magazine, Maclean's, said nothing about the Nanking atrocity. Only in February 1938, did a columnist from London mention Japanese-British relations and a Japanese diplomat's cynical comment referring to Chinese aggression in Shanghai. The emphasis of Maclean's was exclusively Eurocentric, with a single reference in March to the possibility of war coming across the Pacific [72]. Taking The Gazette (Montreal) as a typical English Canadian newspaper, its coverage of the fall of Nanking had no photographs, was based on the Durdin and Abend articles in the New York Times, and only once in December spoke of the Japanese soldiers' "breakdown of discipline". Late in January, in a dispatch from Shanghai headlined "Nanking Captors Run Amok", Abend claimed his sources were based on consular reports whose contents about assaults on women and very young girls were "actually unprintable". A day later, an editorial reiterated the Times' story and Japanese military authorities' admission that the depredations were "blunders". As shocking as this singular news coverage was, the Canadian press did not purchase the extant images to follow-up the story. In the linguistic and cultural gulf that existed between Asia and Canada, the long history of ethnocentricity and conservatism demonstrated the failure of Nanking to register as anything more than a tragic fact [73].

\section{American Newsreels and Nanking}

One of the more puzzling elements surrounding the Nanking Atrocity is the American newsreels' failure to cover the event. Henry Luce's The March of Time, the premier newsreel series of its kind, ignored China in prewar issues, other than a March 1936 mention of
Japan's 1931 invasion of Manchuria. Typically, its narration used "other" voices to mouth potentially hazardous judgments and one issue commented about militant Japan: "but as Japan's militarists march on behind their Emperor, observers may well wonder what a nation whose war dogs go mad at home might do if allowed to run loose throughout the world" ([74], pp. 85, 86). In December 1937, after the Japanese sinking of the USS Panay, nationalist rhetoric inflamed anti-Japanese public opinion.

The March of Time series was a barometer of the growing influence of moving images upon news. It became the most widely distributed newsreel in the United States with an audience of 12 million viewers in 5236 theatres in 168 cities ([74], pp. 138, 154). If there was a dearth of, or no footage available, series director Louis de Rochemont used re-enactment freely ([75]; see [74], pp. 134, 228, 237). In a prewar issue titled "Japan-Master of the Orient", the narrator reviewed Japan's "record of shameful unprovoked aggression" without alluding to the horrors of Nanking. Hesitant to condemn the whole of Japan, he stated, "sober Japanese wonder fearfully how long the patience of the great western nations will brook this lawless threat to the peace of the world" ([74], p. 241). In December 1941 "Battlefields of the Pacific" dealt with Japanese military aggression generally. In fact, between January 1942 and August 1945, the series analyzed the Pacific war in only four issues, devoting one general newsreel to China. The March of Time mentioned Nanking just once in 1942. Ignoring China echoed prewar American isolationist sentiment, owner Henry Luce's laisser faire policy toward the series, its Eurocentric outlook, or Louis de Rochemont's indifference toward the Chinese. Not surprisingly, after December 1941, American interest in the Pacific revolved around concern for American servicemen exclusively ([76]; see [74], pp. 134, 254, 276).

In contrast, a sobering treatment of the Japanese enemy occurred in one of the War Department's propaganda series Why We Fight, made under the supervision of celebrated Hollywood director Frank Capra. In "The Battle of China" (1944), John Magee's Nanking footage was integrated into Chinese-manufactured atrocity images that had appeared in an earlier Canadian newsreel from the National Film Board. Actuality images included a point blank execution of two bound Chinese prisoners, accompanied by the following narration, "but again, Japanese power was too great and after a battle lasting but a few days, the city fell to the invaders. In their occupation of Nanking, the Japs outdid themselves in barbarism. The Japanese soldiers went berserk. They raped and tortured. They killed and butchered. In one of the bloodiest massacres in recorded history, they murdered 40,000 men women and children..." Thus began the Chinese death toll debate ([77], see [54]), but the appalling images showed victims who had been stabbed, raped, set on fire or nearly beheaded ([78]; see [20], pp. 156-157). 
The graphic narration spared nothing. "...But those who lived might better have died, for the horror of their twisted and torn bodies was worse than death... This nightmare of cruelty was all the more horrible because it was deliberately planned by the Japanese high command to tear the heart out of the Chinese people once and forever..." [79].

One can surmise how engaging and effective this inflammatory imagery was, even if the audience for this film was much smaller than the first film in this series "Prelude to War", which was mandatory viewing for millions of American recruits. Released in the fall of 1944, "The Battle of China" was withdrawn briefly, and then reissued midway through 1945, reaching an audience of 3.75 million. One critic has labeled it Hollywood fairy-tale propaganda that strained credibility because it ignored Mao's communist armies (Communism was still a forbidden word in mainstream American media) and pretended that China was expelling the Japanese invader ([80], pp. 176, 184).

The images trigger revulsion, but the propaganda objective was to engage viewers to believe that the Chinese themselves would defeat the enemy. The narration boasted, "...and then it happened. That which Sun Yat Sen had dreamed of, that which Chiang KaiShek had toiled for, that which is stronger than stone walls that had surrounded China: the will to resist. In their last bloody blow the Japanese had accomplished that which four thousand years had failed to bring into being-a united China..." Accompanying this verbiage were pictures of Chinese leaders exhorting their people, reiterating the message of unity. The race card was played more viciously as the narration concluded that Japan planned to conquer North America and the world when "the Germans would join with their buck-toothed pals coming over from Siberia" [80]. If nothing else, racism could be counted on to generate emotion.

\section{Canadian Newsreels and Asia}

For its part, Canada's military engagement in Asia had proven to be disastrous in 1941, with the fall of Hong Kong and the ignominious surrender of two ill trained and unseasoned Canadian battalions ([81]; see [82], p. 109). Learning of Japanese brutality toward all prisoners of war, Canada's film propaganda chief, John Grierson, tried to rally morale without stoking racist fires. On the heels of these military fiascos, this was a difficult task, since the Canadian populace largely approved the government's racially motivated removal of Japanese Canadians from coastal British Columbia in 1942 ([83]; see [84], pp. 82-96).

Invited to Canada in 1939 to establish and then lead the National Film Board, Grierson produced morale building theatrical and nontheatrical short films monthly to inform citizens and soldiers. Emphasizing propaganda as "education", the films systematically shaped perceptions, manipulated cognitions and dir- ected behavior ([85], pp. 11, 78-89). Film Board productions included four theatrical issues on Asia from 1942 to 1944, Inside Fighting China, The Mask of Nippon, When Asia Speaks and Fortress Japan. These newsreels, reaching two million at home and up to ten million internationally, defined Canada's Asian propaganda strategy: to vilify Japanese aggression, not the Japanese people. In July 1942 Inside Fighting China showed the film clip (described above) of Japanese executing Chinese captives. Lorne Greene, the paternal voice of democracy in Canada's wartime newsreels, asserted soberly that the Japanese were using liquid fire, gas, and bacterial warfare to butcher civilians and soldiers. The narration concluded that China, with communists and nationalists united, was destroying the myth of Nippon the invulnerable. There was no mention of the Nanking atrocity ([4], pp. 215-216, 224-225).

Grierson's propaganda approach was ideologically simple: portray the Japanese as individually trustworthy but collectively treacherous. This theme was central to The Mask of Nippon, in September 1942. The film began with a crude physical characterization of Japanese soldiers as "little men, quick and wiry; their uniforms slovenly, their faces, even in the heat of battle, tawny masks, black, expressionless". There followed a series of quick cuts to Japanese troops in combat, and a shot of Japanese soldiers brutalizing a crowd of Chinese civilians, with one seizing and rough-handling a mother and child. Then another threw the child into the air as the other's bayonet pitched the child's body out of the frame. There followed clips of bound Chinese prisoners being thrown into a pit, being buried alive, shot at point blank range, and finally civilians dragging a corpse, literally in ribbons. The narration was accompanied by a chorus of female screams, heightened by a high pitched Oriental flute. This was the most atrocity-filled war footage ever shown to Canadians. The crowd scene, the burying alive of prisoners, the woman, and the bayoneted child were in fact staged, taken from a Chinese-made propaganda film and inserted as actuality footage along with segments of the Magee film. Mixing black (staged) and white (authentic) propaganda was allowable if the result articulated the true larger picture. The narration made reference neither to Nanking nor to the provenance of the footage. The evocative impact of soldiers bayoneting the child remained indelible as audiences would have absorbed the whole as "authentic". A number of stills from the staged sequences continue today to be used, (probably unknowingly), as actuality photographs from Nanking. A wall of verbiage, accompanied by stock iconography of Japanese cultural images, reminded the viewer that the enemy was dangerous, but beatable psychologically and militarily. In July 1944 Fortress Japan gave an account of the Allied advance on beleaguered Japan, using footage of dead Japanese soldiers to demonstrate that the Allied drive would 
break Japan's militaristic spirit: "and so, a nation which has ever held life cheap, prepares to practice once again its ancient arts of death..." Tom Daly, the editor, defended these Asia films, noting that they did not substitute emotional racism for a true thing nor did they deny the Japanese were intelligent people. $\mathrm{He}$ and director/writer Stuart Legg had no misgivings about using the Chinese-manufactured (black) propaganda to drive home the point. Black propaganda is usually defined as material where the role of the authorities is deliberately obscured, or where it appears to come from the people at which it is aimed. Audiences had no idea that the most brutal images were staged sequences ([4], pp. 219-220) (Figure 11).

Figure 11. 'Child' (a doll) bayoneted in Chinese propaganda film. Source: National Film Board of Canada.

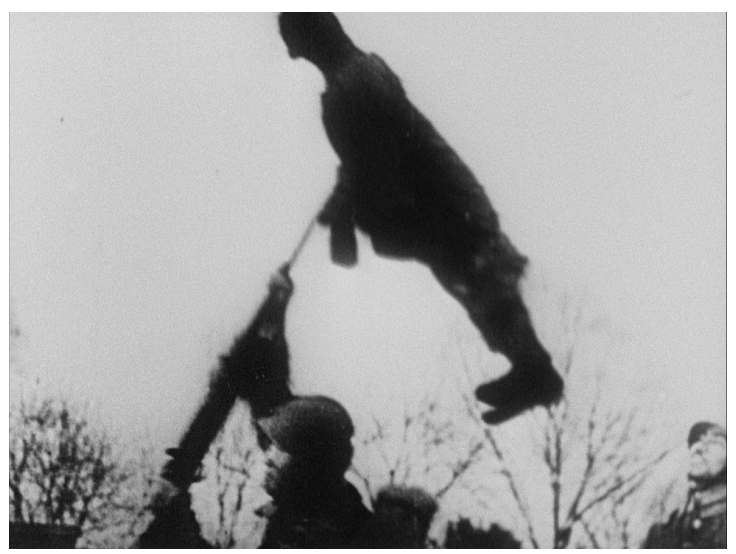

\section{Japanese Propaganda and the Nanking Atrocity}

If Canada's propaganda tried to keep truth as its touchstone, the Japanese had no qualms about employing black propaganda in their sophisticated campaign to deny the Nanking atrocity. The Japanese public learned of the fall and occupation of Nanking through jingoist headlines and newsreel pictures of the victory parade led by their triumphant general. The Japan Advertiser boasted of a barbaric contest between two lieutenants as to who could behead more Chinese prisoners. The tally of 106 to 105 led them to call lightheartedly for a new contest to resolve which of them to name the "winner". After the war, the Allied Wartime Tribunal used the celebrated "killing contest" to condemn the two to hanging for war crimes ([20], pp. 170-171; [86]; see also [54], pp. 141, 147). Many in this culture that celebrated "bushido" never understood why (Figure 12).

Sanitized Japanese newsreels showed troops fighting their way into Nanking, followed by "Bonsai" victory salutes on the city walls. To offset rumors at home of civilian atrocities, Tokyo invited Japanese visitors to tour the city in January 1938. The tourists gave sweets to Chinese children and saw nothing of the ongoing rape and carnage. Japanese newsmen took pictures of "spon- taneous" New-Year's celebrations in which gleeful residents also welcomed Japanese soldiers who handed out sweets (Figure 13). Other photographs depicted children receiving care from a Japanese medical doctor.

Figure 12. Japanese soldiers' killing contest. Source: The Japan Advertiser.

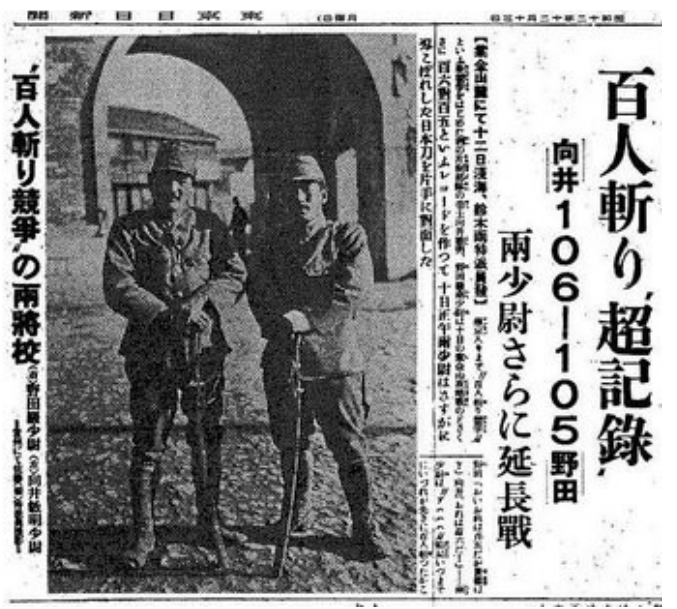

Figure 13. Japanese soldiers handing out sweets to Chinese children. Source: The Japan Advertiser.

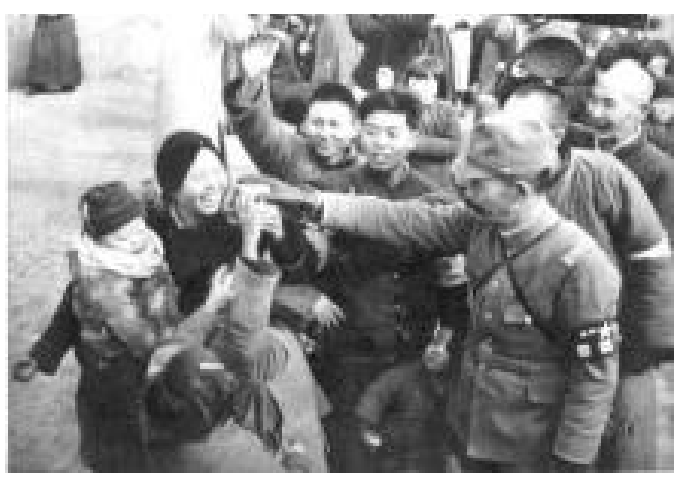

Figure 14. Japanese propaganda in China. Source: Unknown Japanese.

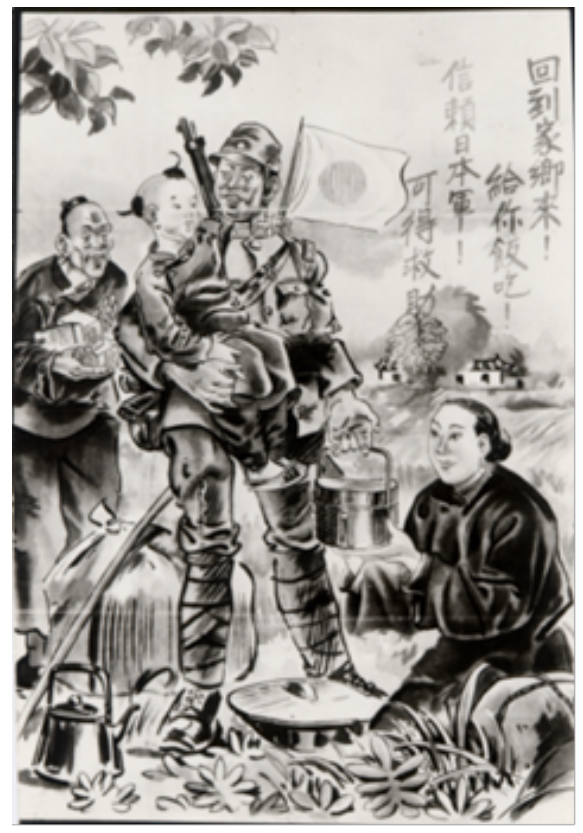


A few reports had the audacity to declare that the Chinese, not the Japanese, were responsible for the looting, raping and burning. The occupying forces also dropped leaflets promising food and clothing if the Chinese returned to their homes. Thousands of hopeful victims left refugee camps in response to a leaflet featuring a Japanese soldier holding a Chinese child in his arms and distributing rice by the bagful (Figure 14). Black propaganda beckoned Chinese to return to their homes to receive food and clothing. Undisciplined Japanese troops then victimized many who returned [87].

\section{Conclusion}

This study has argued that because the world was not yet buried in a surfeit of images, pictures commanded a degree of moral authority. Decades later, a stark postmodernist view articulated by Susan Sontag insisted that photographs from "the slaughter bench of history" do not necessarily induce pathos and sentiment, nor are they the source of ethical and political knowledge. She divorced moral and ethical judgment from the experience of viewing, in part because of the sheer volume of images in our daily lives. In contrast, John Taylor denies that the surfeit of images provokes weariness and distrust, claiming instead that the very awfulness of images can and does define civility. Modernism needs reconsideration, he believes, and through it we remember the importance of images' connection to morality ([59], pp. 1-11).

Observing the still photographs and newsreels devoted to Japanese depredations in Nanking, a number of salient points emerge. In the relatively new practice of twentieth century mass spectatorship, there came into being a new public discourse and public sphere in which media-generated imagery operated on both conscious and unconscious levels ([61], pp. 112, 113). It is not possible to state with certainty the effect of the images upon the millions who experienced them but it is likely that the widely circulated still photographs in LIFE and LOOK contributed to changing or confirming public opinion about militant Japan. Iconic photographs such as those of baby Ping Mei in the ruins of a Shanghai railway station or Japanese soldiers bayoneting Chinese POWs compelled a degree of moral awareness. Though the event was about far away alien victimization, the pain and identification they projected were, we believe, unmistakable. In 1937 the world was on the brink of conflagration and even if their impact is dulled by context and time, their power to summon humanist impulses stands in contrast to Sontag's insistence that images blunt morality and serve to promote pathos and sentiment ([39], pp. 43, 44, 175, 176).

Earlier we observed the prewar sinking of the American gunboat Panay. It had a probable catalytic effect on the public that interpreted it emotionally as a national affront, not only because it was captured on film, but also because the press reinforced its importance for weeks. The lines of patrons at newsreel theatres demonstrated the American public's taste for "news" as images, as sentiment, and even in the prewar world, as a form of jingoist sport. Whatever the motivation, later public opinion surveys demonstrated American sympathies were measurably pro-China and anti-Japan following exposure to the visual and print information.

That said, the trauma of being a combatant in war produced a willingness in both the United States and Canada to use images as public opinion leaders employing white and black propaganda. One can appreciate how the "Rape of Nanking", synonymous with Japanese barbarity, assumed its iconic role. The 1942 and 1944 newsreel pictures of the Nanking atrocities reinforced anti-Japanese public opinion at the least. If John Magee's actuality footage from Nanking and staged images of panicked civilians in The March of Time stirred American audiences to demand revenge, so too did the lurid theatrical bayoneting of the child in Canada's newsreel, The Mask of Nippon. But propaganda chief John Grierson insisted that such images should be balanced by showing the human side of the Japanese; Canada's propaganda goal was to ensure that patterns of peace, not revenge, ultimately prevailed ([88], pp. 140,142, 143, 150, 151; see also [89], pp. 79-92). Being wartime, no one went on record to protest suspected image manipulation, a clear suspicion if one analyzes the perfectly positioned camera and actors. In Japan, the "killing contest" aside, (citizens in Japan's militarist society accepted the warrior's cliché Kill or Be Killed) the Japanese produced their own black propaganda to convince citizens of their humane treatment of the Chinese noncombatant population. One may conclude that if such images had their intended salutary effect, later evidence demonstrates they were dishonest to the core.

One of the great tragedies in recounting the Nanking event is the issue of females being "taken away" as witness Lewis Smythe expressed it so delicately in 1938. The "comfort women" controversy of the 1990s, triggered by current feminist discourse, raised the issue of sexual slavery and sexual assault, but little about the history that led to it. The fact that the Japanese command never planned for the sexual needs of its occupying troops was one catalyst that led to widespread rape ([13], pp. 115-148). Subsequently, Japan attached (mainly Korean) "comfort women" to its troops to prevent a similar catastrophe from recurring. As well, such depredations were meant to humiliate the conquered populations. Today these surviving Korean females wait for a full public apology. Years later, Japanese servicemen's 'souvenir photographs' of the female depredations served to demonstrate how powerful a photograph can be in terms of its ability to enrage civilized consciousness, no matter what the citizenship of the beholder is, and to remind one that 
suppression of the transgression of wartime rape is too often ignored in consideration of public propriety. Today the photograph below of this shamefully humiliated victim stands in a prominent place in the Nanjing Massacre Memorial Hall (Figure 15).

One is reminded of John Taylor's reference to how images of horror function cognitively as a peculiar blend of fear and disgust. They are both an affront and threat that people may share. Citing John Keane, he reminds us of how exposure to horror functions to keep memories alive, to heighten awareness of current cruelties, to raise issues about whether violence is justified, and to encourage remedies for savagery. At the same time one never knows if viewers respond to pictures and film with curiosity, esthetic distance or emotional involvement. What we have demonstrated in this research is that preserved images become part of historical memory [90-92]. Life and Look's publication of atrocious photographs posed the question of what standard was used to decide what was proper to see. It is clear that a regular diet of such images would have provoked reactions of disgust, hence the media themselves determined taste and tone. This study has documented their chronology and contribution to historical public discourse. Once war came, the moving images of Nanking served to remind the public that the enemy's acts had been hateful and that common action would lead to Japan's defeat. Republishing these images in 2014 is meant to waken the public from moral slumber, indifference and historical amnesia and to remind present and future perpetrators around the world that there must be a reckoning for their crimes against humanity.

Why did China let Nanking slip from postwar public scrutiny? A faltering Nationalist China ignored the atrocity in exchange for Japanese political support in the late 1940s; after the Communists formed China's government in 1949, their own political expediency demanded that the shame be ignored. Since the 1990s, circulation of Nanking atrocity photographs has revitalized the event's iconic status. This relates to the emergence of a confident China, where nationalists at home and abroad demand historical justice, as well as to surviving Korean "comfort women" who claim the same. Japan's revisionists refuse to face history squarely because this would require that nation to relinquish its postwar status as victim. Contemporary conservative guardians continue to ignore the Nanking atrocity in Japan's history books. Japanese denial of scope and depth aside, the Nanking outrage serves a positive propaganda function of reminding governments that they are answerable for the acts of their soldiers. New generations of soldiers and civilian collaborators need to know that if they are told to obey and to ignore their conscience, they must, in the long run, answer in the court of posterity.

The absence of official postwar Japanese regret or willingness to pay reparations can be explained by Cold War politics that made it easier for public memory to lapse ([20], pp. 209-214; [93,94]). Iris Chang concluded that Japan's refusal to accept responsibility for the victims of Nanking was a reflection of human nature: she thought unspeakable acts become banalities if they occur far enough away to pose no personal threat $([20]$, p. $221 ;[95,96])$. That is one sad conclusion to draw about the Japanese war in Asia. American postwar interest in Japan had more to do with establishing a constitution and democracy than with accounting for Japanese brutality in China. As historians, some perpetrators, and many in the public now demand an explanation for this historical crime, one recalls Holocaust survivor Elie Wiesel's sober words "Whoever hears a witness to the Holocaust becomes a witness and messenger too" [97]. The unleashing of the Japanese soldiers on Nanking should not be allowed to stand as only another sad statistic of human misery. We believe the images referred to in this study impose rather than create a space for meanings ([98], pp. 3-5) and serve a double purpose: they monumentalize shame until Japan accepts its moral responsibility, after which proper mourning and the integration of the collective memory of both Japan and China will be satisfied. Second, they may also serve to help Japan adopt the politics of atonement officially. If this results in some lingering private resentment, at the very least, it will at last force a fair and ongoing public dialogue between Asia's two Great Powers.

Figure 15. The humiliation of sexually ravaged women. Source: Nanjing Massacre Memorial Hall.

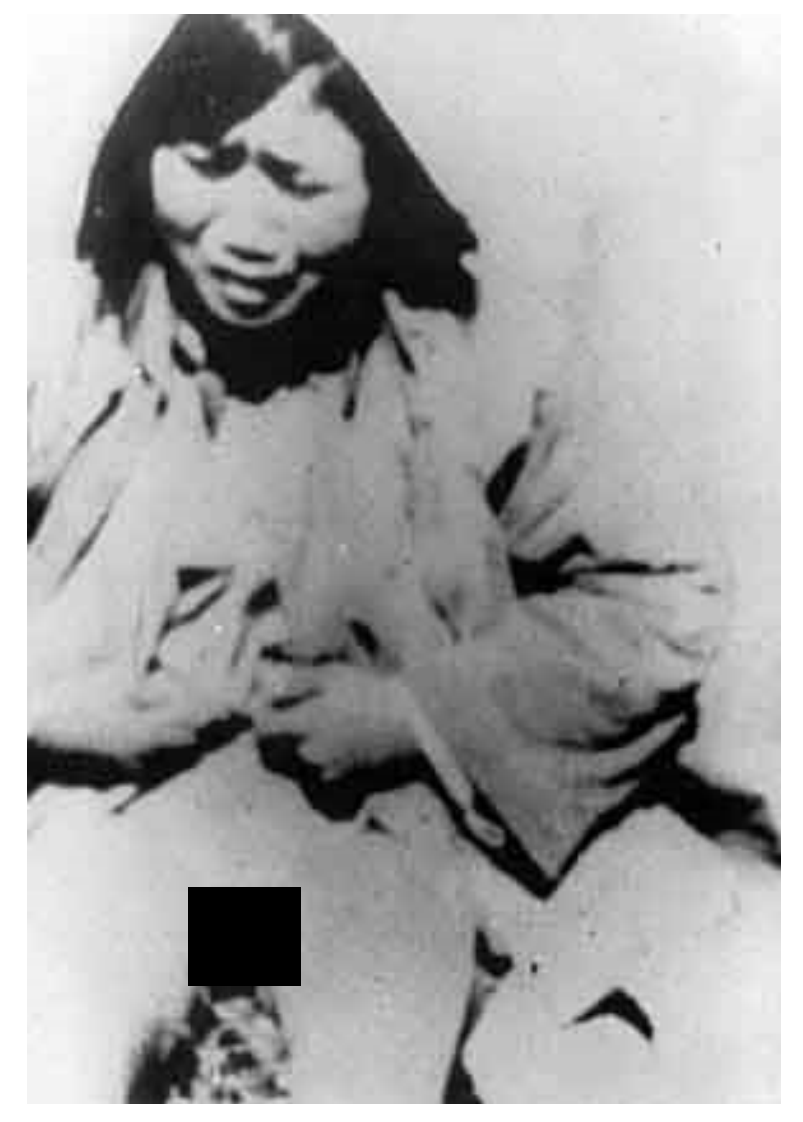




\section{References and Notes}

1. Sontag S. On Photography. New York, NY, USA: Farrar Strauss and Giroux; 1977.

2. Looking at War. The New Yorker. 9 December 2002. pp. 82-98. Available from: www.college.colom bia.edu/core/files/pages/Sontag-essay.pdf (accessed on 18 November 2013).

3. Hopkinson T, editor. Picture Post 1938-50. Harmondsworth, UK: Penguin; 1970.

4. Evans G. John Grierson and the National Film Board: The Politics of Wartime Propaganda 1939-1945. Toronto, Canada: University of Toronto Press; 1984.

5. Stott W. Documentary Expression and Thirties America. New York, NY, USA: Oxford University Press; 1978.

6. Roeder Jr G. The Censored War. New Haven, CT, USA: Yale University Press; 1993.

7. Linfield $S$. The Cruel Radiance. Chicago, IL, USA: University of Chicago; 2010.

8. Linfield embraces the power of photography and takes issue with Sontag's criticism of the medium's deep emotional bite. Linfield rebukes intellectuals like Barthes, Berger and key postmodernists who probed an image's spectacle, emotion and absence of context.

9. A contemporary variation of this is China's interest to use the event to promote nationalism while simultaneously reining in overenthusiastic activists.

10. Fogel $J A$, editor. The Nanjing Massacre in History and Historiography. Berkeley, CA, USA: University of California Press; 2000.

11. Chang I. The Rape of Nanking: The Forgotten Holocaust of World War II. New York, NY, USA: Basic Books; 1997.

12. Yoshida T. The Making of the "Rape of Nanking": History and Memory in Japan, China and the United States. New York, NY, USA: Oxford University Press; 2006.

13. Wakabayashi BT, editor. The Nanking Atrocity 1937-38: Complicating the Picture. New York, NY, USA: Berghahn Books; 2007.

14. This book of contributions by sixteen authors deals with an overview of the event, the debate over victim figures, perpetrators and collaborators, and the ongoing issue of Japanese denial. Its detailed methodology points the way for other researchers to follow. The Japanese deniers' argument is that most Chinese civilian deaths resulted from justifiable legal battlefield actions against unlawful combatants who were armed or had access to arms in the Nanking Safety Zone. They maintain (ignoring the illegal invasion and occupation of China) that no deliberate massacre took place for which Japan must apologize or pay compensation (pp. 359-360). Wakabayashi's own conclusion of 40,000 to 200,000 victims from August to December 1937 reduces the issue to an argument about numbers (p. 384). Numerically speaking, the Nanking count of between 40,000 and 369,000 victims pales next to the Jewish losses of between 5.2 and 5.8 million. If the Japanese unleashed deadly weaponry against Nanking's prisoners of war and committed rape and pillage of numerous civilians, the Germans committed wholesale industrial murder against their victims, root and branch. An historical irony is that in1938, LIFE magazine referred to the tragedy of Nanking as a "holocaust", seven years before that word took on its contemporary meaning referring to the judeocide.

15. Nanking, Christmas 1937 by Yim Ho (Hong Kong), The Truth About Nanjing by Satoru Mizushima (Japan), and Nanking by Bill Gutentag and Dan Sturman (United States). These films present the subject from each national optic. Lust, Caution by Ang Lee, (Hai Sheng Productions, 2007) is a romantic drama set during the occupation of Shanghai. See also City of Life and Death (2009) which is suffused with the violence, death and sexual depredations that accompanied the Rape of Nanking.

16. The postwar Tokyo War Crimes Trial (1947) established a total number of 300,000 killed and 20,000 raped. Present research estimates of Chinese murdered vary widely from 40,000 (by Japanese authors) to over 369,000 (by Chinese authors). Rapes are even more difficult to document because of the shame and stigma associated with victims of this crime.

17. Masahiro Yamamoto [18] discusses the two approaches that now characterize interpretations of the Rape of Nanking as traditionalist and revisionist. He spends considerable effort detailing extant figures on the killings, but concludes that wide divergences between Japanese and other sources keep from bringing both sides to closure. He spends much less energy discussing the rapes and other civilian depredations (pp. 135-138) than he does arguing about numbers killed. He circumvents the elemental question of Japanese aggression in China.

18. Yamamoto M. Nanking, Anatomy of an Atrocity. Westport, CT, USA: Praeger; 2000.

19. In The Name of the Emperor, a National Film Board of Canada production in 1998, directed by Hong Kong filmmakers Christine Choy and Nancy Tong. A number of Japanese veterans confess to committing pillage, rape and murder on orders from their officers. This makes the issue of numbers far less important than the issue of agency. One has only to follow the chain of command to realize that the Rape of Nanking is undoubtedly a war crime that was official (unwritten until documents prove otherwise) policy. NFB C9197 186 [no longer in NFB distribution]. Several perpetrators admitted their war crimes in this film. Iris Chang transcribed several of these admissions in her essay "The Rape of Nanking" [20]. Similar ground is covered in the docudrama Iris Chang: The Rape of Nanking [21].

20. Chang I. The Rape of Nanking. In: Barstow AL, editor. War's Dirty Secret: Rape Prostitution and Other Crimes against Women. Cleveland, OH, USA: The Pilgrim Press; 2000. pp. 46-56. 
21. Spahic B, Pick A, directors. Iris Chang: The Rape of Nanking. Toronto, Canada: Real to Reel Productions; 2007.

22. The Panay story also played out nationally in the San Francisco Chronicle, the Los Angeles Times, the Des Moines Register, the Omaha World Herald, the Dallas News, the Little Rock Gazette, the Boise Idaho Statesman, the Phoenix Arizona Republican and the Kansas City Star.

23. The New York Times. 17 December 1937.

24. MacDonald C. 'Kill All, Burn All, Loot All': The Nanking Massacre of December 1937 and Japanese Policy in China. In: Levene M, Roberts P, editors. The Massacre in History. New York, NY, USA: Berghahn Books; 1999. pp. 223-246.

25. Perlmutter [26] notes that by November, 1938, United States direct aid to China grew from \$20 million to $\$ 100$ million. As well, national support for an embargo against Japan grew (pp. 5-6).

26. Perlmutter D. Photojournalism and Foreign Policy. Westport, CT, USA: Praeger; 1998.

27. Brook T, editor. Documents on the Rape of Nanking. Ann Arbor, MI, USA: Ann Arbor Paperbacks; 1999.

28. Timothy Brook [27] contains much cogent evidence for the atrocities.

29. The newsreel footage of the sinking of the Panay is available free online as [30].

30. The Bombing of the USS Panay, 1938. Available from: https://archive.org/details/SinkingOfUssPanay (accessed on 18 November 2013).

31. Herzstein R. Henry R. Luce, Time and the American Crusade in Asia. New York, NY, USA: Cambridge University Press; 2005.

32. Perlmutter D. Picturing China in American Press: Visual Portrayal of Sino-American Relations in Time Magazine 1949-1973. Lanham, MA, USA: Lexington Books; 2007.

33. The Luce press' portrayal of China as victim of Japanese aggression spurred the United States to enact embargoes on sales of critical resources such as oil, which set the stage for Japan's attack on Pearl Harbor (xviii).

34. LOOK magazine. 21 December 1937. pp. 52-53.

35. A full description of the photographs and captions follows. Title: "A Chinese Baby Survives an Air Raid", Text: "On August 28, while hundreds of terrified Chinese huddled in Shanghai's South Station, 16 Japanese planes bombed the building. Two hundred were killed. The dramatic rescue of a child survivor is pictured here."; Photo: "Chinese man picks up baby found lying on the railroad track at bombardment of train station in August 1937", Text: "An Infant Survivor of the Japanese bombardment of Shanghai's South Station was found lying on the railroad tracks half hidden under the wreckage. Here a young Chinese man picks up the infant, starts for the opposite platform"; Photo: "Man with baby picking way through wreckage", Text: "The Baby Howls as his rescuer picks his way through the wreckage. When the bombs struck South Station it was jammed with poor Chinese waiting to escape war-torn Shanghai on a train to the south. Two hundred were killed"; Photo: "Man crossing tracks nearing platform". Text: "They Near the Platform...Two squadrons of 8 planes each bombed the station. At the same time, they bombed Nantoa, a native residential section of South Shanghai. A civilian section, Nantoa was totally unprepared for the raid and the planes flew away unharmed after the bombing. Previously the Japanese had announced they might issue a warning if Nantoa were to be bombed, but the actual attack came without warning"; Photo: "Rescuer leaves baby on platform", Text: Rescuer Leaves the Terrified Baby on the platform and returns to the wreckage to help other victims of the raid. Then a child and man approach (above) to take the baby to a near- by first aid station. At the right lies the body of a 14-year-old boy, one of the 15 children found dead in the raid. In bombing Shanghai, Japan struck at China's largest, wealthiest city. Planes also have bombed Nanking, China's capital"; Photo: "A child lies on a stretcher as adult hands tend to his wounds", Text: "Lying on a Stretcher on a sidewalk, the baby receives first aid from a Chinese boy scout... Three weeks later, on the occasion of the Japanese bombing of Nanking, the governments of the U.S., Britain and France sent a note of protest to the Japanese government against the bombing of civilian populations. But aerial raids continue, with an increasing toll of dead. Chinese bombers and gunners, as well as Japanese, have been responsible for some of the deaths of innocent non-combatants-American and European as well as Oriental-in this undeclared war" (International News photographs).

36. Fielding R. The American Newsreel, 1911-1967. Norman, OK, USA: University of Oklahoma; 1972.

37. Jespersen CT. American Images of China 193149. Stanford, CA, USA: Stanford University Press; 1996.

38. Time's circulation was $1,000,000$. The photo's effect was so powerful that when Madame Chiang KaiShek arrived in the United States five years later, a New Jersey homemaker sent her a letter with three dollars to "help the little guy on the railroad tracks somewhere in China". Hariman and Lucaites, in No Caption Needed [39], identified the four traits or cultural conventions of an iconic photograph: wide recognition, a historically significant event, evoking a strong emotional response, and widespread reproduction (p. 85).

39. Hariman R, Lucaites JL. No Caption Needed. Chicago, IL, USA: University of Chicago Press; 2007.

40. Historian David Perlmutter supports the Hariman and Lucaites thesis ([39], pp. 3-8) that iconic images dominate public opinion, with a caveat noting the importance of individual predispositions and values. See Perlmutter ([41], pp. 2-19). See also W.J. Thomas Mitchell [42]. 
41. Perlmutter D. Photojournalism and Foreign Policy: Icons of Outrage in International Crises. Westport, CN, USA: Praeger; 1998.

42. Mitchell WJT. Picture Theory: Essays on Verbal and Visual Representation. Chicago, IL, USA: University of Chicago Press; 1994.

43. The graphic description adds to the disgust this image provokes. Interestingly, this appears to be one of the first times the word "holocaust" was used to describe the brutality that ranks among the most heinous that modern state machinery can provoke. The Nazi destruction of the Jews of Europe widened its definition from 1945 on to mean the Jewish genocide.

44. Roeder mentions that America suppressed similar wartime images, such as a 1945 photo of a Japanese soldier's severed head ([6], p. 148).

45. LIFE. 10 January 1938.

46. LIFE. 18 April 1938.

47. George Fitch, who had been in Nanking, smuggled the Magee film out of China and circulated it to many civic groups in the prewar period in an effort to convince Washington to cease selling scrap metal to Japan. Poor health prevented him from showing the film more frequently and he gave it to $\mathrm{Ar}$ thur N. Bierkle who screened it to groups mainly in southern California. Wider dissemination occurred when The March of Time used some of the footage in 1942 and Frank Capra used segments in his wartime series Why We Fight: The Battle for China, 1944.

48. Nanjing Massacre (Sharon Kuykendall 17 April 1996). Available from: http://humanum.arts.cuhk.edu. hk/NanjingMassacre/NMMage.html (accessed on 18 November 2013).

49. LIFE. 30 May and 20 June 1938.

50. See LIFE issues 1,15 August 1938; 17 October 1938; 7, 14, 21 November 1938; 5, 12 December 1938.

51. LOOK. 22 November 1938.

52. This photo was cropped and published again on 20 December 1938.

53. The photo and article are reproduced in [54]. The best known written accounts were by Harold $\mathrm{J}$. Timperley [55] and Lewis Smythe [56].

54. Young S, Yin J. The Rape of Nanking: An Undeniable History in Photographs. Chicago, IL, USA: Innovative Publishing Group; 1997.

55. Timperley $\mathrm{HJ}$. The Japanese Terror in China. New York, NY, USA: Modern Age Books; 1938.

56. Smythe L. War Damage in the Nanking Area, December 1937 to March 1938. Shanghai, China: Mercury Press; 1938.

57. In spite of the continuing coverage of the China warfront, Henry Luce's LIFE spent the majority of its efforts on events in Europe through 1938. There was no further reference to the Nanking atrocity.

58. Further bibliographic and philosophical speculation about atrocity photographs may be found in the earlier mentioned Sontag article in The New Yorker. See also [59] as well as Linfield's The Cruel Radiance
[7]. Linfield believes that photojournalism has come to play a role in the establishment of human rights legislation. Two other approaches to this subject are [60] and ([61], pp. 117, 155-156).

59. Taylor J. Body Horror. Photojournalism, Catastrophe and War. Manchester, UK: Manchester University Press; 1998.

60. Messaris P. Visual Literacy: Image Mind and Reality. Boulder, CO, USA: Westview Press; 1994.

61. Newton JH. The Burden of Visual Truth: The Role of Photojournalism in Mediating Reality. Mahwah, NJ, USA: Erlbaum; 2001.

62. Joshua A. Fogel [10] follows the transformation of this event into an icon. The chapter titles are: Nanjing Massacre in History; Aggression Victimization and Chinese Historiography of the Nanjing Massacre; Battle over History: Nanjing Massacre in Japan; Challenges of the Nanjing Massacre: Reflections on Historical Inquiry.

63. Mark Eykholt [64] states that the brutality and primitive behaviour ran against Western society's conviction that the Japanese were civilized, hence would not commit such crimes.

64. Eykholt M. Aggression, Victimization, and Chinese Historiography of the Nanjing Massacre. In: Fogel JA, editor. The Nanjing Massacre in History and Historiography. Berkeley, CA, USA: University of California Press; 2000.

65. In the past decade, see accounts of the Asian perspective on the war in Christopher Bayly and Tim Harper $[66,67]$. See too Mitter [68] as well as Hotta [69].

66. Bayly C, Harper T. Forgotten Armies. London, UK: Penguin; 2005.

67. Bayly C, Harper T. Forgotten Wars. Belknap Press of Harvard University Press; 2007.

68. Mitter R. Forgotten Ally: China's World War II, 1937-1945. New York, NY, USA: Houghton Mifflin Harcourt; 2013.

69. Hotta E. Japan 1941: Countdown to Infamy. New York, NY, USA: Knopf; 2013.

70. Deluca [71] argues that in iconic images, iconic becomes transcendent and that images transform rhetoric, politics and history, citing Walter Benjamin, who said we are immersed in a torrent of imagery that constitutes public discourse. (79-89) There should be more methodological investigation of how the widely circulated newsreel images of the Japanese attack on Pearl Harbor (especially footage of the exploding battleship Arizona) became iconic in convincing the American public to wage the Pacific war as a war of revenge.

71. Deluca KM. The Speed of Immanent Images: The Dangers of Reading Photographs. In: Hope DS, editor. Visual Communication: Perception, Rhetoric and Technology. Cresskill, NJ, USA: Hampton Press; 2006.

72. Maclean's. 15 February and 15 March 1938.

73. New York Times reporters filed reports on the 
fall of Nanking. These were edited by the Gazette on 8,10 , and 11 December with one article on the 22nd devoting one line to a 'breakdown of discipline'. 25 January marked the first reference to the 'scandalous' conditions of 'lawlessness and bestiality'. A day later an editorial repeated the main points and explained that Japan had forbidden foreign reporters to cable responsible editorial comments. On 8 February an article stated that General Matsui admitted that the army had run amok in Nanking, 'raping Chinese women, shooting private citizens and looting property'. These were the sole references to the Nanking atrocities.

74. Fielding R. The March of Time, 1935-1951. New York, NY, USA: Oxford University Press; 1978.

75. Luce interfered rarely in the series produced by Louis de Rochemont, if only to make Chiang Kai Shek a sacred cow. The construction of the newsreel was left to de Rochemont who made decisions on what to run.

76. The series' Pacific war issues were Crisis in the Pacific, China Fights Back, The Philippines and Australia at War.

77. The discussion of the total death toll includes the 1948 estimate of 200,000 to a more recent statistic of 369,366 , which includes 190,000 victims of mass killings and 150,000 victims of random killings including rape (pp. 242-244). Japanese officer Toshio Ohta discussed body disposal at Xiaguan where 30,000 soldiers and 120,000 civilians including elders, women and children were disposed of (p. 260). Revisionist scholarship of the 1990s challenged this so-called traditionalist interpretation. Revisionists have cut by more than half the 300,000 plus figure, though the figure of at least 20,000 or more rapes seems not to be an issue for them.

78. Fitch's film evidence appeared in the 1990s in two documentaries, Testament by Magee and In the Name of the Emperor by Choy and Tong.

79. Capra F, director. Why We Fight. No. 6 "The Battle of China". Maydace Video; 1944.

80. Culbert D.'Why We Fight': Social Engineering for a Democratic Society at War. In: Short KRM, editor. Film and Radio Propaganda in World War II. Knoxville, TN, USA: University of Tennesee Press; 1983.

81. 557 Canadians perished in battle or in Japanese prison camps.

82. Morton D. Canada and War. Toronto, Canada: Butterworths; 1981.

83. In 1942 the Red Cross reported that the Canadian commanding officer stated the prisoners were well treated and they could not complain about the food.
84. Roy PE, Granatstein JL, Iino M, Takamura $\mathrm{H}$. The Hong Kong Disaster. In: Granatstein JL, Neary P. The Good Fight: Canadians and World War II. Toronto, Canada: Copp Clark; 1995.

85. Grierson J. Grierson on Documentary. London, UK: Collins, 1946.

86. The photo section shows the newspaper with the lieutenants posing.

87. Wakabayashi [13] features a chapter in part defending the perpetrators (pp. 115-148).

88. Aitken I. The Documentary Film Movement: An Anthology. Edinburgh, UK: Edinburgh University Press; 1988.

89. Evans G. John Grierson: Trailblazer of Documentary Film. Montreal, Canada: XYZ Publishing; 2005.

90. In Body Horror [59], Taylor refers to Devereaux and Hillman [91] as well as to John Keane [92].

91. Devereaux L, Hillman R, editors. Fields of Vision, Essays in Film Studies, Visual Anthropology and Photography. Berkeley, CA, USA: University of California Press; 1995.

92. Keane J. Reflections on Violence. London, UK: Verso; 1996.

93. There have been tentative steps to rectify this as some hundreds of interviews with or diaries of former Japanese soldiers have been recorded in the past 15 years. These should strengthen the case for Japan accepting its moral responsibility for the atrocity in order to bring closure. Takahashi Yoshida [94] documents how many Japanese veterans' recorded experiences attest to the extent and destructiveness of the army's rampage. Many such confessions appear in the docudrama Iris Chang: The Rape of Nanking [21].

94. Yoshida T. A Battle over History in Japan. In: Fogel JA, editor. The Nanjing Massacre in History and Historiography. Berkeley, CA, USA: University of California Press; 2000.

95. A recent article by Yinan He [96] asserted that China's political elite may not control the national mythmaking process and that dissenting views held by the public at large were often motivated by patriotism. He does not consider the role of collective memory as activated by such imagery as we have discussed here.

96. He Y. Remembering and Forgetting the War: Elite Mythmaking, Mass Reaction and Sino-Japanese Relations 1950-2006. History and Memory. 2007;19 (2):43-74.

97. Bonisteel $\mathrm{R}$, director. From the Ashes: Conversation with Elie Wiesel. CBC Television; 1973.

98. Hardt $\mathrm{H}$, Brennan B. Picturing the Past. Champaign, IL, USA: University of Illinois Press; 1999. 